\title{
SIDATRAT: Informatics to Improve HIV/AIDS Care
}

\author{
Carlos Aragonés BEng MS, Jorge R. Campos, Daniel Pérez MD MS, Alina Martínez MPharm, Jorge Pérez MD MS
}

\begin{abstract}
AIDS is a major cause of death in the Caribbean, a region with a high prevalence of HIV. However, prevalence in Cuba's population aged 15 to 49 years, despite a slight increase in recent years, is considered extremely low (0.1\%). At the close of 2010, 5692 Cuban patients were receiving antiretroviral therapy. SIDATRAT, an informatics system, was developed at the Pedro Kourí Tropical Medicine Institute in Havana to ensure proper monitoring and followup of drug administration. Functioning on a web platform utilizing an Apache server, PHP and MySQL, it records patients' general information, CD4 counts, viral load and data from other laboratory tests, as well as endoscopic and imaging studies. It also compiles information on their AIDS classification, opportunistic infections, HIV subtype and resistance studies, followup consultations, drug regimen, adverse reactions to medications, changes in drug combinations, and survival; and tracks total number of individuals under treatment. SIDATRAT follows the client-server philosophy and enables access by authorized users throughout Cuba via the health informatics network. SIDATRAT has been found effective in supporting quality care for persons living with HIVIAIDS and universal access to antiretroviral therapy, compiling most of the information needed for decisionmaking on patient health and therapies. SIDATRAT has been offered to the UNDP office in Havana for sharing with other developing countries that may wish to adapt or implement it.
\end{abstract}

\section{QUALITY CARE REQUIRES QUALITY INFORMATION}

The AIDS epidemic has evolved over the last three decades and continues to be a global health priority. Access to antiretroviral therapy reached $42 \%$ global coverage in 2008; [1] in December 2009, an estimated 5.2 million people living with HIVIAIDS in low- and middle-income countries were receiving antiretroviral therapy, a 30\% increase over the same period the previous year.[2]

Care for people living with HIV is one of the greatest challenges for health systems, providers and their institutions,[3] and requires access by physicians and other health professionals to accurate and comprehensive information.[4] Effective treatment requires innovative methods of disseminating knowledge and information to ensure delivery and monitoring of quality services.[3] Depending on available infrastructure and human resources, different strategies can be used to manage HIVIAIDS information,[5] ranging from independent databases with communications and alerts by e-mail to web-based digital medical registries. Use of digital HIVIAIDS medical registries in developing countries has been shown to be effective in supporting provision of quality medical care, including antiretroviral therapy.[6-10]

AIDS is a major cause of death in the Caribbean, where high HIV prevalence is also recorded.[1] Even with a slight increase in recent years,[1] Cuba maintains an extremely low prevalence of $0.1 \%$ in the population aged 15 to 49 years.[11] From 1986 through 2011, 15,824 persons were diagnosed with HIV, 80.8\% of them men.[12] HIV transmission in Cuba has occurred mainly between men who have sex with men.[13] By the end of 2011, 2455 people had died of AIDS.[14]
From 1986 to 1993, Cubans diagnosed with HIV were institutionalized and attended exclusively in the 14 sanatoria set up in various provinces, a strategy provoking considerable debate.[15-18] At the end of 1993, the Ministry of Public Health (MINSAP, the Spanish acronym) implemented an ambulatory care system[19] aimed at social reinsertion of persons living with HIV. By late 2008, 74\% of HIV-diagnosed persons in Cuba were enrolled in the ambulatory care system and $26 \%$ lived in the sanatorial system, now called comprehensive care centers for persons with HIVIAIDS (some there temporarily while completing the Learning to Live with HIV training program).[20]

Until 1996 some patients received antiretroviral monotherapy or bitherapy. From 1996 to 2001, a small number of patients received triple therapy, mainly thanks to drug donations from abroad. Since 2001, with domestic production of several generic medications,[19] antiretroviral therapy (ART) became a standard regimen, free of charge to patients.[14,19] More therapeutic combinations were introduced starting in 2003, with support from the Global Fund to Fight AIDS, Tuberculosis and Malaria (Global Fund). The same year, Cuba achieved universal ART access[19] for all those meeting clinical eligibility criteria: confirmed HIV infection, CD4 lymphocyte count of less than 350 cells $/ \mathrm{mm}^{3}$, viral load of more than 55,000 copies $/ \mathrm{mL}$ and opportunistic infection. [21] By close of 2009, over 4000 persons living with HIVIAIDS were receiving treatment,[11] and by close of 2010, 5692 persons were receiving ART.[13]

ART use has been found effective in Cuba, with improvement in immunological parameters and survival rates, fewer opportunistic infections and lower AIDS-related mortality.[19,22] However, drug resistance and treatment failure associated with non-adherence have been documented.[22,23] Thus, achieving high adherence levels has become a priority health strategy for Cuba's National Response Program to HIVIAIDS.[24]

This Program depends on strict control and monitoring to ensure satisfactory followup and medication delivery to every patient receiving ART. In a country with limited economic resources such as Cuba, this requires special attention: for example, it is vitally important to know the exact number of persons under treatment in each locale, as well as the combinations prescribed, to ensure supply continuity and avoid shortages. Furthermore, for sound decisionmaking, attending physicians and other health professionals involved in treating persons living with HIVIAIDS need immediate and secure access to clinical information on their patients, especially CD4 lymphocyte counts, viral loads and previous therapeutic combinations.[4,25]

This paper describes the experience of the Pedro Kourí Tropical Medicine Institute (IPK, the Spanish acronym) in implementing an informatics tool to support clinical followup and ART of persons living with HIVIAIDS.

\section{SIDATRAT DEVELOPMENT}

Since the onset of the HIV epidemic in Cuba, IPK has been a national reference center for specialized care of persons with 


\section{SIDATRAT Users Comment}

Primary-care physicians on patient followup
Through SIDATRAT we have access to all our patients' clinical informa-
tion, which has been extremely useful for our work.
-Dr Omar Torres, Pinar del Río province
I use SIDATRAT every day; it is a great help, and easy to manage. I
print the CD4 and viral load graphs to explain the results to my patients.
-Dr Arturo Viñas, Havana province
Summarizing information: a support tool for research
SIDATRAT has been very useful in my work to obtain my master's
degree in infectology. It enabled me to access epidemiological informa-
tion on CD4 count, viral load and treatment of my patients.
-Dr José Manuel Borroto, Havana
Monitoring regional compliance with patient followup standards
SIDATRAT provides us immediate access to clinical data on our
patients, and has been an important tool for achieving quality of care.
-Dr Niurka Rocha, Havana
Source for calculating national indicators
We use SIDATRAT as a source of information to monitor and evaluate
reports from Global Fund-supported projects; it is highly reliable.
-Ana Luisa Castellanos, Ministry of Foreign Trade and Investment
SIDATRAT is a useful information tool for logistical management of proj-
ects financed by the Global Fund in which UNDP is a responsible party.
-Wolker Velter, UNDP advisor

opportunistic AIDS-related infections and for training health care providers in clinical approaches to HIVIAIDS. Since 2001, IPK has led implementation of the Cuban government's strategy to provide universal access to ART for those patients requiring it.

SIDATRAT arose in response to the need to ensure appropriate control and clinical followup for ART patients.

The first version of SIDATRAT was launched in 2001, consisting of a Microsoft Access database located at the IPK[19] that compiled patients' data: general (from MINSAP's AIDS limitedaccess data system), opportunistic infections; clinical information including stage of HIVIAIDS infection, viral load and CD4 counts; treatments; adverse reactions to medications; and studies on therapeutic resistance and adherence.[5] Communication with provinces to update information was done via telephone and email. Compiling all this data in one place had great initial impact, given that the IPK measured only viral load and CD4 count, while all other tests were conducted in provincial hospitals and sanatoria.[19]

SIDATRAT's second generation was launched in 2005. It was web based and utilized an Apache server, PHP and MySQL, enabling use of a client-server platform. The servers were located at the IPK and connection by authorized provincial users was assured through INFOMED, the public health system's nationwide telematics network.[26] This version has continued to evolve, including new specialized services and functions to help improve information quality and patient care.

By 2008, all information on CD4 count, viral load and treatment of persons living with HIVIAIDS in the country was registered in SIDATRAT. As decentralized comprehensive ambulatory care for persons living with HIVIAIDS was strengthened at the primary care level,[27] new services were established in various provinces to measure patients' CD4 count and viral load. But these data were not incorporated into SIDATRAT. Since 2009, due to administrative MINSAP decisions, SIDATRAT contains primarily followup data on patients receiving treatment at the IPK (those in all western provinces plus serious cases seen from throughout the country), with updated data available to physicians anywhere in the country whose HIV patients are seen at the IPK.

\section{SIDATRAT FEATURES}

General patient data SIDATRAT is updated with general data on patients from MINSAP's AIDS limited-access data system. These include: first and last name, gender, date of birth, date of diagnosis, age at time of diagnosis, municipality and province of residence, and date of AIDS onset. All such general information is entered by system administrators, and personnel from IPK services entered data on doctor visits, clinical condition and treatment. Attending physicians, in both IPK and municipalities, have access only to information on their own patients, while provincial or regional health personnel in the HIVIAIDS program can access aggregate data on patients in their province or region registered in SIDATRAT. The system allows multiple reports to be generated from different combinations of these variables (see Figure 1).

Figure 1: Screenshot of menu for generating reports from general patient information

\begin{tabular}{|c|c|c|c|c|}
\hline Registro a utilizar: & OVIH/SIDA & OVariadex & OAuxiliar & Líneas por Página: $50 \mathrm{v}$ \\
\hline \multicolumn{2}{|c|}{ Ordenar por: Caso Indice } & $v$ & \multicolumn{2}{|l|}{ Condiciones: } \\
\hline \multicolumn{2}{|l|}{ Datos a Mostrar: } & & Contiene: & \\
\hline ĐCaso Indice & $\square$ Sistema & DFecha Nacim. & Sexo: [ & Or.Sexual: Todas $v$ \\
\hline ĐNúmero $\mathrm{HC}$ & 口fecha Diagn. & पpiel & Provincia: & STGO DE CUBA \\
\hline$\square$ Carné Identidad & $\square$ Caso SIDA & $\square$ Estado Civil & Municipio: & CONTRAMAESTRE $\mathrm{v}$ \\
\hline ĐNombre & $\square$ sIDA con Tto & $\square$ Nivel Escolar & Sistema: & N.Escol: Todos \\
\hline ĐPrimer Apellido & $\square$ Tto No SIDA & ఐProfesión & Fecha Diagn:: & 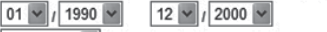 \\
\hline$\square$ Segundo Apellido & $\square$ fallecido & $\square$ ocupación & Fallecido: & Vivos \\
\hline Đsexo & $\square$ Fecha Fallecido & Dorient Sexual & Fecha Fall:: [ & 叫 \\
\hline$\square$ Municipio & $\square$ Reside & & Reside en: & LA HABANA \\
\hline$\square$ Provincia & 口Edad al Diagn. & & Edad: & Al Diagn: $15-19 \vee$ Actual: $35-39 \vee$ \\
\hline
\end{tabular}

Patient followup data SIDATRAT records CD4 counts, viral loads and the results of other lab tests, as well as endoscopic and imaging studies, AIDS classification, opportunistic infections, subtype and resistance studies, and the scheduling and attending of followup visits. The tool permits extracting reports, totals and graphics from information compiled from laboratories and other services. These are helpful to physicians for making treatment decisions (see Figure 2). Decisionmakers can see which patients are not attending followup appointments or have not had CD4 or viral load studies in a period of time, and track tests conducted (see Figure 3).

ART management The system registers persons in treatment, regimen composition, schedules, number of tablets per day, adverse drug reactions, locations of pharmacies providing medications, and reasons for prescription or treatment changes. It calculates results indicators and patient survival over a given period. By continually updating each patient's treatment plan, SIDATRAT can identify drug needs for each locale, which is useful to ensure uninterrupted treatment. The system can display the total number of patients using each medication and combination, as well their province of residence. It can calculate total requirements over a given period for each registered locale, province or the entire country. It can alert physicians about patients with low CD4 counts 
Figure 2: Sample patient CD4 counts and viral loads over time

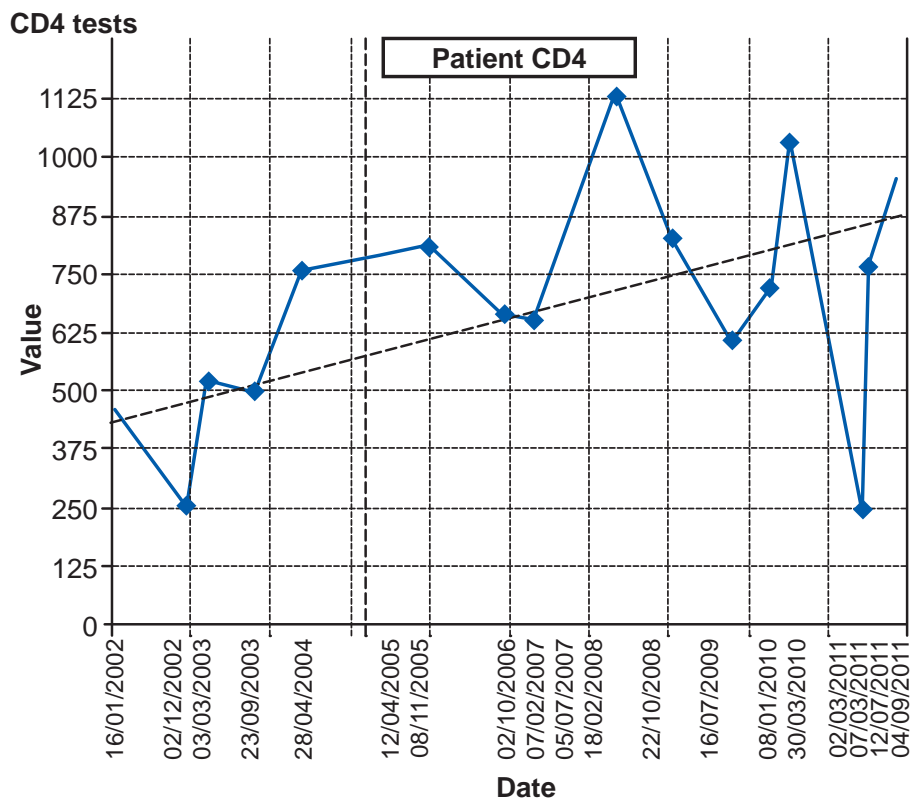

Viral loads

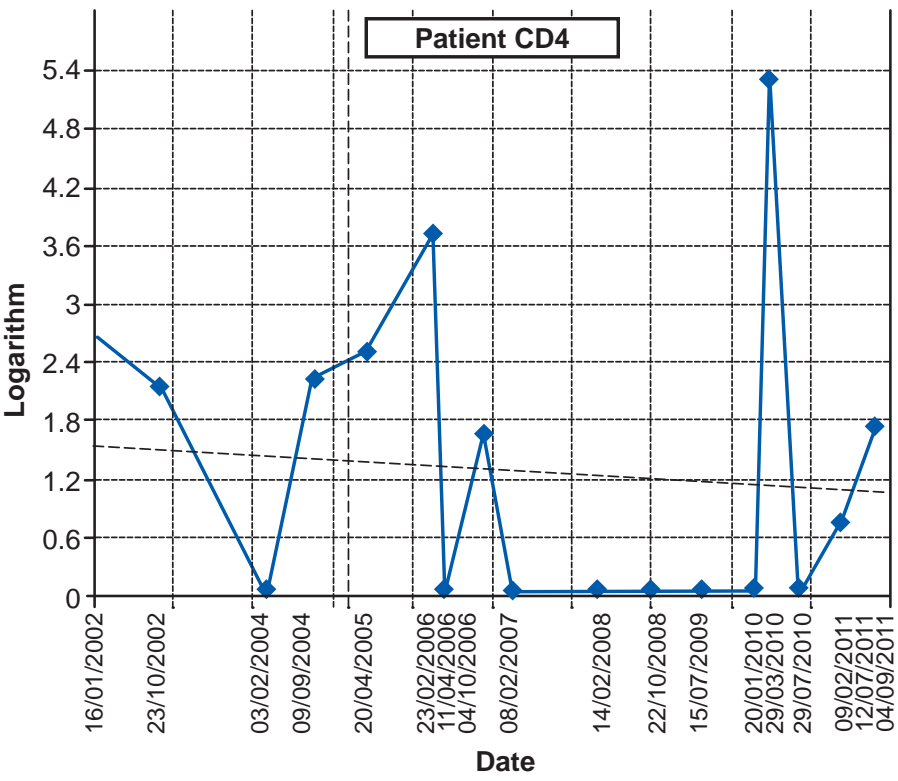

or high viral loads who have not yet started treatment, and about patients in treatment who are not seeing their doctor for followup. Thus, attending physicians have access to the information they need to prescribe or change antiretroviral therapy.

Information security and confidentiality The central SIDATRAT server is installed at and functions from the IPK network. It is certified and meets national information security standards established by the Ministry of Informatics and Communications' Office for Security of Information Networks.[28]

Authorized users are issued a user ID and secure password to access SIDATRAT through INFOMED, enabling communication among professionals and technicians of national health system institutions.[26,29] Users' system roles (administration, write/ read, read only, access to patient information, connection from local or national network) are defined based on the function they perform and their information needs. Their tasks are defined by a) where they work - specialized laboratories, pharmacies, medical registries, outpatient services, treatment commission (an expert group that decides treatment plans), imaging departments or; b) in the case of phisicians, by the patients in their care. A dynamic menu is constructed for each user, with access dependent on approved privileges.

Each access event is recorded, including date, log-on time, log-off time, and IP address. All webpages visited and searches conducted are recorded to monitor information use and protect confidentiality. A system administrator monitors operations daily, including all user access events and actions. The database is backed up to external hard drives three times a day.

\section{EXPERIENCE WITH SIDATRAT}

Since 2005, the current version of SIDATRAT has been used for daily patient monitoring, as a research tool, for regional monitoring and to calculate territorial indicators. The system includes e-mail and instant message services, enabling real-time communication among users, including specialists in medical registries, imaging, and laboratory medicine; as well as physicians treating individuals with HIVIAIDS at IPK, comprehensive care centers for persons with HIVIAIDS and in their municipalities. These services are particularly helpful for new specialists who need advice and support from more experienced colleagues across the country.

By December 2011, SIDATRAT had registered 15,824 HIVdiagnosed persons, 6814 of these patients in ART. This includes 104,781 CD4 counts; 30,994 viral loads; and 14,321 prescribed treatments and changes in treatment. As a result, SIDATRAT has identified the most common drug combinations as: lamivudine + nevirapine + zidovudine (48\%) and lamivudine + nevirapine + estavudine (15\%). The primary reasons for changing treatment have been adverse reactions to medication, among them: skin rash in patients using nevirapine, nausea and vomiting with indinavir, and anemia in patients using zidovudine. Lipodistrophy has been observed in the combination of protease inhibitors and estavudine.

Problems and challenges Although the system is highly userfriendly, physicians and other health professionals who begin

Figure 3: CD4 tests performed annually at IPK, 2000-2010

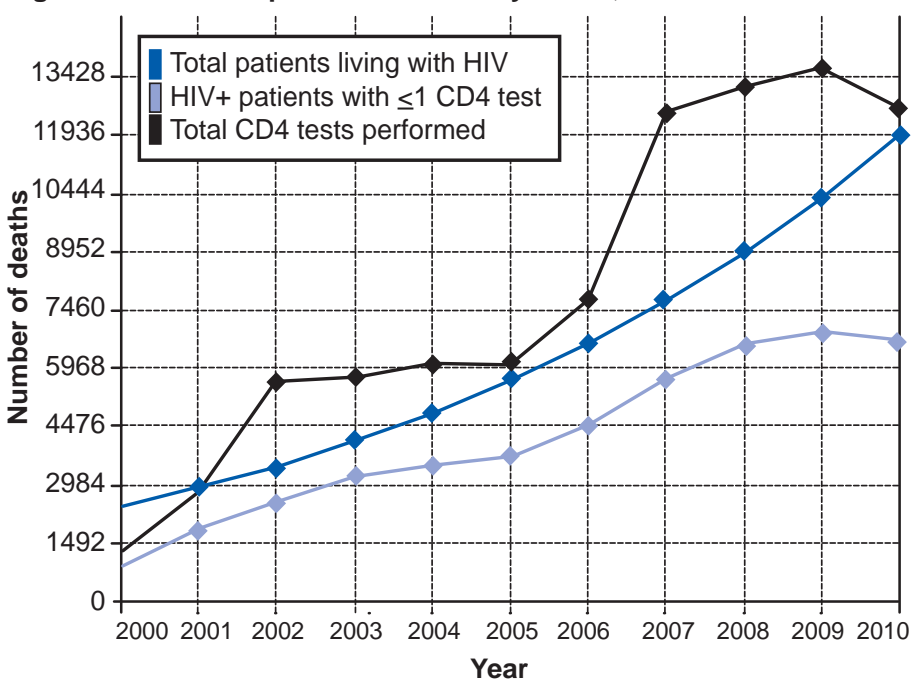


working with SIDATRAT receive training and educational sessions to familiarize them with the system and its options. A search tool has been developed to help SIDATRAT users and administrators find patients whose names have been recorded incorrectly, who are concurrently receiving more than one treatment, or who die while in active treatment.

The two SIDATRAT administrators, who work full-time at IPK, periodically review information quality and completeness, following up with personnel in charge when data are missing. Maintaining updated clinical records is a key challenge to maintaining the system functional. IPK has increased the numbers of computers and trained staff in areas supplying information to SIDATRAT, understood as a contribution to improving quality of care for persons living with HIVIAIDS.

\section{AN EVOLVNG SYSTEM FOR AN EVOLVING EPIDEMIC}

The first version of SIDATRAT permitted more rapid and complete adoption of clinical guidelines by medical personnel attending persons with HIVIAIDS. As with similar local efforts in the USA[24] and Malawi,[30] SIDATRAT could be implemented at relatively low cost with local resources and great potential to improve medical care. In general, implementation of an informatics system such as this is a difficult and expensive activity calling for substantial interaction between the hospital installing it and the supplier.[31] In this case, SIDATRAT was developed in IPK's biostatistics and informatics department (registered in the National Copyright Center, CENDA: \#2941-2008).
The web version of SIDATRAT, similar to a telemedicine project in Mali,[32] facilitates interchange with experts by remote connection and maintains good infrastructure and national-level access, which helps clinics meet their information needs.[33] At the same time, it demands strict compliance with established security standards for digitized health information.[34]

Our experience is that patients attending periodic checkups at IPK and in the various municipalities feel more confident and secure when the physician can show them monitoring graphs of CD4 counts and viral loads, directly on screen or in hard copy. Similarly, health personnel report finding it helpful to use images to explain to their patients the changes in different parameters related to their health status.

Future development of SIDATRAT includes protocols for research studies involving persons living with HIVIAIDS in the areas of pathological anatomy, nephrology and dermatology. Tools to connect SIDATRAT with laboratory equipment have been developed, helping reduce data entry errors and thus improving information quality.[35] Expanded use of SIDATRAT in Cuba could support researchers and decisionmakers in undertaking a variety of studies related to disease progression, treatment evolution, therapeutic adherence and compliance with clinical followup. SIDATRAT has been offered to the UNDP in Havana for sharing with other developing countries interested in adapting it to their conditions to contribute to better care and followup of persons living with HIV. W

\section{REFERENCES}

1. AIDS epidemic update [Internet]. Geneva: UNAIDS; 2009 [cited 2010 May 27]. 100 p. Available from: http://www.unaids.org/en/media/unaids/contentassets/ dataimport/pub/report/2009/jc1700_epi_update_2009_en.pdf.

2. UNAIDS report on the global AIDS epidemic 2010 [Internet]. Geneva: UNAIDS: 2010 [cited 2011 Aug 08]. 364 p. Available from: http://www.unaids.org/en/ media/unaids/contentassets/documents/unaidspublication/2010/20101123 globalreport_en.pdf.

3. Safran C, Rind DM, Davis RB, Ives D, Sands DZ, Currier J, et al. Guidelines for management of HIV infection with computer-based patient's record. Lancet. 1995 Aug 5;346(8971):341-6.

4. Pakenham-Walsh N, Priestly C, Smith R. Meeting the information needs of health workers in developing countries. BMJ. 1997 Jan 11;314(7074):90.

5. Fraser HS, Jazayeri D, Nevil P, Karacaoglu Y, Farmer PE, Lyon E, et al. An information system and medical record to support HIV treatment in rural Haiti. BMJ. 2004 Nov 13;329(7475):1142 -6.

6. Nucita A, Bernava GM, Bartolo M, Masi FD, Giglio P, Peroni M, et al. A global approach to the management of EMR (electronic medical records) of patients with HIVIAIDS in sub-Saharan Africa: the experience of DREAM software. BMC Med Inform Decis Mak. 2009 Sep 11;9:42

7. Braitstein P, Einterz RM, Sidle JE, Kimaiyo S, Tierney W. "Talkin' about a revolution": How electronic health records can facilitate the scale-up of HIV care and treatment and catalyze primary care in resource-constrained settings. J Acquir Immune Defic Syndr. 2009 Nov;52 Suppl 1:S54-7.

8. Forster M, Bailey C, Brinkhof MW, Graber C, Boulle A, Spohr M, et al. Electronic medical record systems, data quality and loss to follow-up: survey of antiretroviral therapy programmes in resource-limited settings. Bull World Health Organ. 2008 Dec;86(12):939-47.

9. Zabat GM, Caoili JC, Anduyon A, Ramos GJ, Morin MJ, Ditangco RA, et al. Design and implementation of an HIVIAIDS electronic medical record system (HIVIAIDS EMR) in the Philippines. AMIAAnnu Symp Proc. 2007 Oct 11:1166

10. Tierney WM, Rotich JK, Hannan TJ, Siika AM, Biondich PG, Mamlin BW, et al. The AMPATH medical record system: creating, implementing, and sustaining an electronic medical record system to support HIVIAIDS care in western Kenya. Stud Health Technol Inform. 2007;129(Pt 1):372-6.

11. Armas Padrino I. La prevención, mejor antídoto contra el SIDA. Granma. 2009 Dec 1. Spanish

12. Ministry of Public Health (CU). Informe nacional sobre los progresos realizados en la aplicación del UNGASS. La Habana 2012 [Internet]. Geneva: UNAIDS; 2012 [cited 2012 Sep 1]. 69 p. Available from: http://www.unaids. org/es/dataanalysis/knowyourresponse/countryprogressreports/2012countri es/file,68500,es.pdf. Spanish.

13. de Arazoza H, Joanes J, Lounes R, Legeai C, Clémençon S, Pérez J, et al. The HIVIAIDS epidemic in Cuba: description and tentative explanation of its low HIV prevalence. BMC Infect Dis. 2007 Nov 9;7:130.

14. Pérez Avila LJ. Infección por VIH en Cuba. Resultados del tratamiento antirretroviral. Paper presented at IX Evento Científico de GPSIDA; 2012 Jun; Sanatorio de Santiago de Las Vegas, Havana. Spanish.

15. Santana S, Faas L, Wald K. Human immunodeficiency virus in Cuba: the public health response of a Third World country. Int J Health Serv. 1991;21(3):511-37.

16. Bayer R, Healton C. Controlling AIDS in Cuba. The logic of quarantine. N Eng J Med. 1989 Apr 13;320(15):1022-4.

17. Pérez-Stable EJ. Cuba's response to the HIV epidemic. Am J Public Health 1991 May;81(5):563-7.

18. Scheper-Hughes N. AIDS, public health, and human rights in Cuba. Lancet 1993 Oct 16:342(8877):965-7.

19. Pérez J, Pérez D, González I, Díaz Jidy M, Orta M, Aragonés C, et al. Approaches to the Management of HIVIAIDS in Cuba. Geneva: World Health Organization; 2004. 19 p.

20. Surveillance System, National Program on HIVIAIDS. Havana: Ministry of Public Health (CU); 2009.

21. Pérez J, Pérez D, González I, Díaz M, Millán JC, Orta M. Pautas cubanas para el tratamiento antirretroviral en los pacientes con VIH/SIDA. Havana: Ministry of Public Health (CU); 2004. Spanish.

22. Pérez L, Álvarez LP, Carmona R, Aragonés C, Delgado E, Thomson MM, et al. Genotypic resistance to antiretroviral drugs in patients infected with several HIV type 1 genetic forms in Cuba. AIDS Res Hum Retroviruses. 2007 Mar;23(3):407-14

23. Pérez L, Thomson MM, Bleda MJ, Aragonés C, González Z, Pérez J, et al. HIV Type 1 molecular epidemiology in cuba: high genetic diversity, frequent mosaicism, and recent expansion of BG intersubtype recombinant forms. AIDS Res Hum Retroviruses. 2006 Aug;22(8):724-33.

24. Harries AD, Nyangulu DS, Hargreaves NJ, Kaluwa O, Salaniponi FM. Preventing antiretroviral anarchy in sub-Saharan Africa. Lancet. 2001 Aug 4;358(9279):410-4.

25. Kale R. Health information for the developing world. BMJ. 1994 Oct 8;309(6959):939-42.

26. Séror AC. A Case Analysis of INFOMED: The Cuban National Health Care Telecommunications Network and Portal. J Med Internet Res. 2006 Jan 27;8(1):e1. 
27. Estruch L, Santín M, Lantero MI, Ochoa R, Joanes J, Alé K, et al. República de Cuba. Informe nacional sobre los progresos realizados en la aplicación del UNGASS. La Habana [Internet]. Geneva: UNAIDS. 2010 [cited 2010 Jun 20]. 42 p. Available from: http://data.unaids.org/pub/Report/2010/cuba_2010 country progress report es.pdf. Spanish.

28. Reglamento de Seguridad para las Tecnologías de la Información. Havana: Ministry of Informatics and Communications (CU); 2007 [cited 2012 Sept 01]. 14 p. Available from: http://www.di.sld.cu/documentos/resol/REGLAMENTO SEGURIDAD_TI.pdf. Spanish.

29. Delgado A, Gorry C. Cuba's National eHealth Strategy. MEDICC Rev. 2008 Jan;10(1):6-8.

30. Douglas GP, Deula RA, Connor SE. The Lilongwe Central Hospital Patient Management Information System: a success in computer-based order entry where one might least expect it. AMIA Annu Symp Proc. 2003:833.

31. Carnall D. Medical software's free future. BMJ. 2000 Oct 21;321(7267):976.

32. Geissbuhler A, Ly O, Lovis C, L'Haire JF. Telemedicine in Western Africa: lessons learned from a pilot project in Mali, perspectives and recommendations. AMIA Annu Symp Proc. 2003:249-53.

33. Cimino JJ, Li J, Graham M, Currie LM, Allen M, Bakken S, et al. Use of Online Resources While Using a Clinical Information System. AMIA Symp Proc. 2003:175-9.

34. Halamka JD, Szolovits P, Rind D, Safran C. A WWW implementation of national recommendations for protecting electronic health information. J Am Med Inform Assoc. 1997 Nov-Dec;4(6):458-64.

35. Bates $D$, Cohen $M$, Leape $L$, et al. Reducing the frequency of errors in medicine using information technology. J Am Med Inform Assoc. 2001 JulAug;8(4):299-308.

\section{THE AUTHORS}

Carlos Aragonés López (Corresponding author: aragones@ipk.sld.cu), computer sciences engineer with a master's degree in epidemiology. Associate researcher and head, informatics and communications department, Pedro Kourí Tropical Medicine Institute (IPK), Havana, Cuba.

Jorge R. Campos Díaz, informatics technician, informatics and communications department, IPK, Havana, Cuba.

Daniel Pérez Correa, internist with a master's degree in infectious diseases. Adjunct researcher and head of external and emergency services, IPK, Havana, Cuba.

Alina Martínez Rodríguez, pharmacist. Specialist, clinical pharmacology department, IPK, Havana, Cuba.

Jorge Pérez Ávila, physician specializing in pharmacology. Associate researcher and director, IPK, Havana, Cuba.

Submitted: January 14, 2012

Approved for publication: October 16, 2012

Disclosures: None

\section{ERRATUM}

The following erratum has been corrected in all online versions of this article:

Page 7: Figure 2, label for the second graphic should be "Viral load" 